\title{
PENINGKATAN KECEPATAN PENGELUARAN KOLOSTRUM DENGAN PERAWATAN TOTOK PAYUDARA DAN PIJAT OKSITOSIN PADA IBU POST PARTUM
}

\author{
Kuswati, Henik Istikhomah \\ Kementerian Kesehatan Politeknik Kesehatan Surakarta Jurusan Kebidanan
}

\begin{abstract}
Totok Payudara, Oxytocin Massage And Colostrum. The purpose of this study was to determine differences in time of leaking colostrums in mothers post partum in doing oxytocin massage with totok payudara. This study design used is quasiexperimental design with the design Nonequivalent Control Group Design. Reserch conducted at the midwives (BPM) at health centers working area Klaten who were divided into 2 groups, i.e an experimental group consisting of 30 respondens to whom oxytocin massage was given and a control group consisting of 30 responden to whom totok payudara was given. Bivariate data analysis using statistical test used is $t$-test. Results of the study showed the average time of leaking colostrums in experimental and control groups were 152,67 minutes and 137,23 minutes. The result of hypothesis test using T-test obtained the value of $p=0.668$ ( $p>0.05)$. Conclusion: there is no difference time between oxytocin massage and totok payudara to the leaking colostrum
\end{abstract}

Key Word: Totok Payudara, Oxytocin Massage And Colostrum

Abstrak: Perawatan Totok Payudara, Pijat Oksitosin Dan Kolostrum. Tujuan penelitian ini untuk membuktikan apakah ada perbedaan waktu pengeluaran kolostrum pada ibu postpartum yang diberikan tindakan perawatan payudara (totok payudara) dengan pijat oksitosin.Desain penelitian ini Quasi Eksperimen dengan rancangan Nonequivalent Control Group Design. Sampel: sebagian Ibu post partum di BPM wilayah Klaten sejumlah 60 orang yang terbagi dalam 2 group, 30 ibu post partum yang diberikan pijat oksitosin dan $30 \mathrm{ibu}$ post partum kelompok control yang diberikan perawatan totok payudara. Analisis data bivariat menggunakan Uji statistika $\mathrm{t}$ - test. Hasil dari penelitian menunjukkan rerata waktu pengeluaran kolostrum pada kelompok experiment dan kelompok control adalah 152,67 menit and 137,23 menit. Hasil uji hipothesis dengan T-tes tidak ada perbedaan rerata waktu pengeluaran kolostrum antara perawatan totok payudara dengan pijat oksitosin dengan nilai $p$-value $0.668(>0.05)$.

Kata Kunci: Perawatan Totok Payudara, Pijat Oksitosin Dan Kolostrum

\section{PENDAHULUAN}

ASI (Air Susu Ibu) adalah makanan terbaik bagi bayi karena ASI mengandung semua kebutuhan bayi. ASI merupakan sumber nutrisi yang terbaik bagi bayi karena kandungan gizinya lengkap dan seimbang, temperaturnya sesuai dengan yang dibutuhkan bayi. Komposisi nutrien dalam ASI sangat ideal untuk tumbuh kembang anak. Selain itu, ASI meningkatkan kesehatan, membantu untuk mencegah penyakit, dan mengurangi perawatan kesehatan dan biaya makan. (Bartick, 2009). ASI juga melindungi bayi 
dari berbagai penyakit infeksi seperti diare dan muntah, infeksi telinga dan melindungi bayi dari alergi (Pujiadji, 2005). Tidak semua bayi beruntung bisa mendapatkan ASI sesuai kebutuhan yang disebabkan karena ASI yang keluar hanya sedikit atau bahkan tidak keluar sama sekali. Upaya untuk memperlancar produksi ASI masyarakat Indonesia. Upaya untuk menstimulasi pengeluaran ASI telah banyak dilakukan yaitu dengan inisiasi menyusui dini dengan tujuan hisapan bayi pada putting ibu mampu menstimulasi peningkatan produksi hormon laktasi yaitu hormon prolaktin maupun hormon oksitosin. Dalam upaya ini beberapa bayi mampu menemukan putting susu, namun masih banyak bayi belum mampu menemukan putting susu maupun belum mampu menghisap putting ibu, sehingga perlu dilakukan upaya lain untuk menstimulasi produksi kolostrum dan ASI. Tindakan perawatan payudara secara langsung pada kelompok intervensi dapat meningkatkan kecukupan ASI dibanding penyuluhan perawatan payudara pada kelompok kontrol mengunakan leaflet (Indriastuti 2015), perawatan totok payudara merupakan perawatan payudara yang dapat menstimulasi produksi hormon laktasi, karena dengan massage memaksimalkan vaskularisasi pada sistem peredaran darah di kelenjar mamae dan hipotalamus anterior memproduksi hormon sehingga kolostrum maupun ASI dapat lebih cepat keluar. Tindakan pijat oksitosin pada ibu menyusui berpengaruh terhadap peningkatan Kecukupan ASI dilihat dari peningkatan berat badan bayi ,frekuensi menyusu bayi frekuensi BAK bayi dan lama tidur bayi. (Endah KH, 2013). Hasil penelitian Endah Siti Nur 2011 menjelaskan rata - rata waktu pengeluaran kolostrum pada kelompok intervensi pijat oksitosin lebih cepat dibanding kelompok kontrol. Sedangkan hasil penelitian Faizatul ummah 2011 menyimpukan bahwa pijat oksitosin dapat mempercepat pengeluaran ASI.

Memberikan ASI sesuai kebutuhan bayi berarti keuntungan untuk semua, bayi akan lebih sehat, cerdas dan berkepribadian baik, ibu akan lebih sehat dan menarik. Perusahaan, lingkungan, dan masyarakat pun akan lebih mendapat keuntungan. Menurut Azrul Anwar (2004), ASI sangat penting untuk peningkatkan SDM kita di masa yang akan datang, terutama dari segi kecukupan gizi sejak dini (Utami Roesli, 2008).

Data dari data Survei Sosial Ekonomi Nasional pada 2007-2008 menunjukkan bahwa ibu yang memberikan ASI eksklusif 0-6 bulan mengalami penurunan dari $62,2 \%$ pada 2007 menjadi $56,2 \%$ pada 2008. Berarti yang memberikan ASI Eksklusif selama 6 bulan masih rendah (Utami Roesli, 2008). Tingkat pencapaian pemberian ASI eksklusif berdasarkan data dari profil kabupaten atau Kota D.I Yogyakarta tahun 2010 rata rata adalah 42,8\%, terjadi peningkatan bila dibandingkan dengan tahun 2009 yang mencapai 35,28\% (DINKES Yogyakarta, 2011). Cakupan terendah dari ke 5 kabupaten yang ada di Yogyakarta adalah Kabupaten Bantul yaitu 29,9\% dan yang cakupan pemberian ASI eksklusifnya masih rendah berada di Kecamatan Srandakan yaitu 4,5\% (DINKES Bantul, 2011). Pencapaian tersebut dirasakan masih rendah bila di bandingkan dengan target MDG'S tahun 2015 yang diharapkan $80 \%$ bayi mendapat ASI Eksklusif.

Dari hasil survey di wilayah desa jomboran klaten di dapatkan data 8 dari 
10 ibu menyusui tidak memberikan ASI secara ekslusif dengan $70 \%$ penyebab kegagalan adalah adanya masalah payudara yang terdiri dari kurangnya produksi ASI, puting susu lecet dan terjadi pembengkakan payudara ( Marlina 2014).

\section{METODE PENELITIAN}

Desain penelitian ini adalah quasi eksperiment posttest design Sampel dalam penelitian ini adalah ibu post partum di wilayah BPM Klaten sejumlah 60 orang, yaitu kelompok pijat oksitosin sejumlah 30 orang dan kelompok perawatan payudara dengan totok payudara sejumlah 38 orang.

Instrument dalam penelitian ini adalah lembar observasi untuk mencatat lama waktu pengeluaran kolostrum pada ibu post partum dan analisis data dilakukan dengan menggunakan uji t-test.

\section{HASIL PENELITIAN}

Hasil penelitian dideskripsikan sebagai berikut:
Hasil penelitian ditemukan 15\% kelompok umur ibu saat melahirkan berisiko dan sebanyak $85 \%$ kelompok umur ibu saat melahirkan sehat dan normal dan Hasil penelitian ditemukan $1.7 \%$ paritas ibu tergolong berisiko dan sebanyak $98.3 \%$ paritas normal.

Tabel 2

\section{Lama Pengeluaran Kolostrum Pada Kelompok Pijat Oksitosin Dan Kelompok Totok Payudara}

\begin{tabular}{lll}
\hline \multicolumn{1}{c}{ Statistik } & \multicolumn{2}{c}{ Lama pengeluaran kolostrum } \\
& $\begin{array}{l}\text { Kelompok } \\
\text { Pijat } \\
\text { Oksitosin }\end{array}$ & $\begin{array}{l}\text { Kelompok } \\
\text { Totok } \\
\text { Payudara }\end{array}$ \\
\hline Frekuensi & 30 & 30 \\
$\begin{array}{l}\text { Mean } \\
\text { (menit) }\end{array}$ & 152.67 & 137.23 \\
$\begin{array}{l}\text { Standar } \\
\text { Deviasi } \\
\text { (menit) }\end{array}$ & 153.869 & 142.106 \\
$\begin{array}{l}\text { Median } \\
\text { (menit) }\end{array}$ & 67.50 & 77.50 \\
$\begin{array}{l}\text { Minimum } \\
\text { (menit) }\end{array}$ & 20 & 30 \\
$\begin{array}{l}\text { Maksimum } \\
\text { (menit) }\end{array}$ & 625 & 615 \\
\hline
\end{tabular}

Berdasarkan tabel 2. dapat dilihat Tabel 1

Karakteristik Responden berdasarkan Umur dan paritas Responden

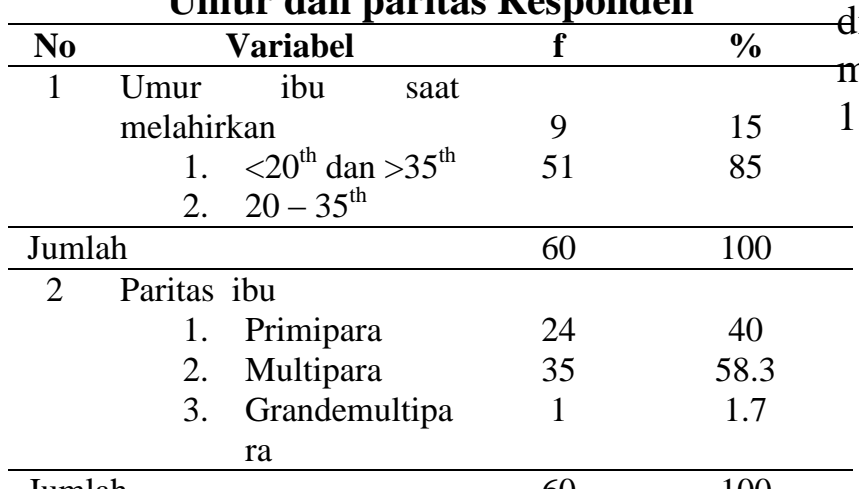

bahwa bahwa rerata waktu pengeluaran kolostrum dari 30 responden yang diberikan pijat oksitosin adalah 152.67 menit sementara kelompok totok payudara 137.23 menit

Tabel 3

Perbedaan Waktu Pengeluaran Kolostrum Ibu Postpartum Yang Dilakukan Pijatan Oksitosin Dan Perawatan Totok Payudara Di Puskesmas Wilayah Klaten

\begin{tabular}{|c|c|c|c|c|c|c|c|}
\hline $\begin{array}{rrr}60 & 100 \\
\end{array}$ & variabel & Perlakuan & $\mathrm{N}$ & Mean & SD & $\mathrm{T}$ & Value \\
\hline Berdasarkan tabel 1 terlihat bahwa & \multirow{2}{*}{$\begin{array}{l}\text { Pengeluaran } \\
\text { kolostrum }\end{array}$} & $\begin{array}{l}\text { Pijat } \\
\text { Oksitosin }\end{array}$ & 30 & 152.67 & $\begin{array}{l}153 . \\
869\end{array}$ & \multirow{2}{*}{$\begin{array}{l}0.4 \\
04\end{array}$} & \multirow[b]{2}{*}{0.688} \\
\hline usia risiko hamil dan bersalin yaitu $<20^{\text {th }}$ & & $\begin{array}{l}\text { Totok } \\
\text { payudara }\end{array}$ & 30 & 137.23 & $\begin{array}{l}143 . \\
106\end{array}$ & & \\
\hline
\end{tabular}
35 tahun kategori tidak berisiko. 


\section{PEMBAHASAN}

\section{Karakteristik Responden berdasarkan} Umur dan paritas Responden

Hasil penelitian ini menunjukkan bahwa distribusi frekuensi responden berdasarkan usia dari 60 responden sebagian besar $81.7 \%$ berumur 20-35 tahun dengan paritas mayoritas adalah mutipara sebesar $61.7 \%$. Umur 20-35 tahun adalah usia reproduksi sehat wanita, pada usia tersebut seorang perempuan sudah siap secara fisik, emosi, psikologis, sosial dan ekonomi untuk hamil (Ruswana, 2006). Salah satu faktor yang mempengaruhi produksiASI adalah faktor fisik ibu yaitu usia ibu. Ibu-ibu yang usianya lebih muda atau kurang dari 35 tahun lebih banyak memproduksi ASI dibandingkan dengan ibu-ibu yang usianya lebih tua (Biancuzo, 2000). Adanya perubahan maternal attainment, terutama pada ibu-ibu yang baru pertama kali mempunyai bayi atau primipara merupakan salah satu faktor psikologis yang juga dapat mempengaruhi kurangnya produksi ASI (Mercer, 2004 dalam Alligood, 2008). Mardiyaningsih (2010) menyatakan paritas juga diperkirakan dapat mempengaruhi produksi ASI. Ibu multipara mempunyai proporsi produksi ASI lebih banyak disbanding ibu primipara. Hal ini dikarenakan ibu multipara telah mempunyai pengalaman dan keyakinan pada saat menyusui sebelumnya. Jika ibu berhasil pada saat menyusui anak pertama maka pada saat menyusui anak kedua akan lebih yakin dapat berhasil untuk menyusui. Keyakinan ibu ini dapat merangsang pengeluaran hormone oksitosin sehingga ASI dapat keluar dengan lancar

\section{Perbedaan Waktu Pengeluaran Kolostrum Ibu Postpartum yang dilakukan pijatan oksitosin dan perawatan totok payudara di Puskesmas wilayah klaten}

Hasil perhitungan dengan analisa statistik T-Test Independent pada 30 responden kelompok pijat oksitosin dan 30 responden kelompok totok payudara didapatkan nilai $\mathrm{p}=0.688(>0,05)$ yang berarti secara statistik Ho diterima dan $\mathrm{Ha}$ ditolak dengan demikian dapat disimpulkan tidak terdapat perbedaan waktu pengeluaran kolostrum antara kelompok pijat oksitosin dan kelompok totok payudara.

Berdasarkan hasil penelitian diatas didapatkan ibu yang diberikan tindakan perawatan payudara dan pijat oksitosin tidak terdapat waktu pengeluaran kolostrum artinya tindakan perawatan payudara sama baiknya dengan tindakan pijat oksitosin. Hasil penelitian ini tidak sejalan dengan penelitian Saragih (2014) dimana perawatan payudara yang baik dan benar memiliki peranan yang penting dalam meningkatkan produksi ASI. Jika dilihat dari tingkat kelancaran ASI, tindakan breast care lebih dominan dalam meningkatkan produksi ASI dibandingkan dengan tindakan pijat oksitosin

Tindakan breast care adalah pemeliharaan payudara yang dilakukan untuk memperlancar pengeluaran ASI dengan melakukan pemijatan. Perawatan payudara sangat penting dilakukan selama hamil sampai menyusui. Breast care mempengaruhi letdown reflex karena ada rangsangan dalam puting susu (Ambarwati ER, 2010). Sedangkan pijat oksitosin merupakan salah satu cara untuk mengatasi ketidaklancaran produksi ASI. Pijat oksitosin adalah pemijatan yang dimulai pada tulang belakang servikal 
(servical vertebrae) sampai tulang belakang torakalis dua belas dan merupakan usaha untuk merangsang hormon prolaktin dan oksitosin setelah melahirkan (Rahmawati N dkk, 2014)

Dilihat perbandingan kedua tindakan di atas, tindakan dengan perawatan payudara tidak lebih dominan dalam mempercepat waktu pengeluaran kolostrum dibandingkan dengan tindakan pijat oksitosin. Produksi ASI dipengaruhi oleh refleks pengaliran atau pelepasan ASI (let- down reflex) setelah diproduksi oleh sumber pembuat susu, ASI akan dikeluarkan dari sumber pembuat susu dan dialirkan ke saluran susu. Tindakan yang dapat dilakukan untuk memperlancar ASI dapat dilakukan dengan breast care dan pijat oksitosin, kedua tehnik tersebut sama-sama merangsang refleks oksitosin atau let down reflex yang membedakannya adalah dari teknik tindakan, dimana breast care mempengaruhi let down reflex karena ada rangsangan dalam puting susu dan disekitar payudara. Sedangkan pijat oksitosin mempengaruhi let down reflex dilakukan dengan pemijatan yang dimulai pada tulang belakang servikal (servical vertebrae) sampai tulang belakang torakalis dua belas. Reflek Pengeluaran ASI terjadi karena sel otot halus di sekitar kelenjar payudara mengerut sehingga memeras ASI untuk keluar.Penyebab otototot itu mengerut adalah suatu hormon yang dinamakan oksitosin. Sehingga dari segi cara, breast care lebih dekat dengan payudara dan hal tersebut mempengaruhi produksi ASI yang lebih banyak dibandingkan dengan pijat oksitosin yang dilakukan pada bagian belakang. Produksi ASI dapat dipengaruhi oleh pikiran, perasaan dan emosi ibu. Menurut Jeremy, refleks oksitosin dapat dipengaruhi oleh pikiran, perasaan dan emosi ibu. Perasaan ibu dapat meningkatkan dan juga menghambat pengeluaran oksitosin. Hormon ini akan menyebabkan sel-sel otot yang mengelilingi saluran pembuat susu mengerut atau berkontraksi sehingga ASI terdorong keluar dari saluran produksi ASI dan mengalir siap untuk dihisap oleh bayi (Jeremy W, dkk, 2009). Sehingga kemungkinan jika ibu memiliki pikiran, perasaan dan emosi yang kuat, maka akan menekan refleks oksitosin dalam menghambat dan menurunkan produksi ASI. Perawatan payudara merupakan suatu usaha yang dilakukan ibu agar kondisi payudara baik, untuk mencapai keberhasilan menyusui. Perawatan payudara bermanfaat merangsang payudara mempengaruhi hipofisis untuk mengeluarkan hormon prolaktin dan oksitosin. Hormon prolaktin darihipofisis anterior mempengaruhi jumlah produksi ASI sedangkan hormon oksitosin dari hipofisis posterior mempengaruhi proses pengeluaran ASI. Prolaktin berkaitan dengan nutrsi ibu, semakin asupan nutrisi baik maka produksi ASI yang dihasilkan juga banyak (Sari YS, 2014).

\section{KESIMPULAN DAN SARAN}

Berdasar hasil analisis data dan pembahasan dapat disimpulkan sebagai berikut: 1) Waktu pengeluaran Kolostrum kelompok pijat oksitosin rata - rata 152,67 menit, sedangkan lama waktu kelompok totok payudara adalah rata rata 137,23 menit.

Hasil uji hipotesis T-Test Independent menunjukkan bahwa nilai $\mathrm{p}$ adalah $0.866 \quad(>0.05)$ sehingga dapat disimpulkan bahwa tidak terdapat perbedaan yang bermakna antara pijat 
oksitosin dan totok payudara terhadap pengeluaran kolostrum.

Saran yang diajukan yaitu:

1. Bagi Instansi Pelayanan Kesehatan (Dinas Kesehatan) Pihak instansi pelayanan kesehatan diharapkan dapat menerapkan intervensi pijat oksitosin dan perawatan payudara (totok payudara) sebagai bentuk intervensi yang membantu kelancaran produksi dan pengeluaran ASI pada ibu post partum.

2. Bagi Tenaga Kesehatan Bidan dapat mengikuti pelatihan konseling menyusui yang di dalamnya terdapat materi tentang cara meningkatkan produksi ASI dengan pemberian intervensi seperti pijat oksitosin maupun perawatan payudara sehingga bidan dapat mengajarkan intervensi ini pada ibu post partum dan diharapkan proses laktasi dapat berjalan lebih optimal.

3. Bagi masyarakat Setelah diberi intervensi dan KIE tentang pijat oksitosin atau perawatan payudara, ibu post partum dapat melakukannya secara mandiri atau dengan dibantu oleh suami dan keluarga. Peran suami dan keluarga akan sangat berpengaruh dalam keberhasilan menyusui.

4. Bagi Peneliti Selanjutnya, hasil penelitian dapat sebagai acuan peneliti lain dan mengembangkan penelitian, yaitu menambah variabel seperti faktor-faktor lain yang mempengaruhi waktu pertama pengeluaran kolostrum.

\section{DAFTAR RUJUKAN}

Anggraini, Y. 2010. Asuhan Kebidanan Masa Nifas. Yogyakarta: Pustaka Rihana
Anwar, S. 2002, Hak Asasi Bayi dan Pekan ASI Sedunia, Alfabeta, Bandung

Azwar, S. 2010, Sikap Manusia Teori dan Pengukurannya, Edisi ke-2, Pustaka Pelajar, Yogyakarta

Bahiyatun. 2009. Buku Ajar Asuhan Kebidanan Nifas Normal. Jakarta: EGC.

Baskoro, A, 2008, ASI, Panduan Praktis Ibu Menyusui, Banyu Media, Yogyakarta

Briawan, D. 2004, Persiapan Menghadapi Laktasi, Gramedia, Jakarta

Lina Pengaruh perawatan payudarapada ibu post partum terhadap kecukupan ASI ,2015

Kementerian Kesehatan RI. 2010, Pedoman Kader Seri Kesehatan Anak, Bakti Husada

Peraturan Pemerintah Republik Indonesia Nomor 33 Tahun 2012, Tentang Pemberian ASI Eksklusif, 2012

Perinasia. 2009, Manajemen Laktasi : Cetakan ke Empat, Tim Penerbit Perinasia (Perkumpulan Perinatologi Indonesia), Jakarta

Poedjawijatna, I.R. 2004, Tahu dan Pengetahuan, Rineka Cipta, Jakarta

Prasetyono, Dwi Sunar, 2009, Buku Pintar ASI Eksklusif, Pengenalan Praktik, dan KemanfaatanKemanfaatannya, DIVA Press, Yogyakarta

Roesli, Utami. 2005, Mengenal ASI Eksklusif, Trubus Agrawijaya, Jakarta

Roesli, Utami. 2008. Inisiasi Menyusu Dini plus ASI Eksklusif, Pustaka Bunda, Jakarta 